\title{
LANDSCAPE-ECOLOGICAL REQUIREMENTS FOR SPATIAL PLANNING OF RURAL TERRITORIES OF UKRAINE
}

\author{
Velta Parsova $^{1}$, Nataliia Stoiko ${ }^{2}$, Nadya Kryshenyk ${ }^{2}$ \\ ${ }^{1}$ Latvia University of Life Sciences and Technologies, Latvia; \\ ${ }^{2}$ Lviv National Agrarian University, Ukraine \\ velta@parsova.lv,n_stoiko@ukr.net,nadya_kryshenyk@ukr.net
}

\begin{abstract}
Land resources of Ukraine, having economic, social, natural, cultural and historical significance, mainly are located within rural areas. Despite the fact that Ukraine has a significant land and resource potential of the territories, intensification of the use of land resources, in particular in agriculture, leads to the depletion of soil cover, land degradation and landscape destruction. The environmental policy of Ukraine provides for introduction of the principles of sustainable development in all fields of environmental management. It is planned to optimize the structure of land use types, reducing the area of arable land by removing eroded slopes, degraded and unproductive land, and water protection areas. The article explores the issues related to the adoption of decisions on the placement of various activities within rural area, which, on the one hand, will satisfy the needs of the population, and on the other hand, will create conditions for the reproduction and preservation of the natural potential of the territories. Such decisions should be based on spatial planning measures, the conceptual basis of it is differentiation of the landscape within the territory. The methodological basis of the study is physical economy, in which economic development is based on the laws of nature. The authors have developed a methodical approach to determine the priority types of land use forming cultural landscape, which, in turn, ensures free movement of biological energy as the basis of life activity. Results of the research are approbated on the example of rural area within the Remezivtsi municipality of district Zolochiv of Lviv region. There is suggested landscape-ecological mapping of rural area, which can be used in the system of integrated land use management.
\end{abstract}

Keywords: land use, landscape-ecological approach, physical economy, rural area, spatial planning.

\section{Introduction}

To perform efficiency of state management in the field of regional development in Ukraine, it is foreseen to improve the system of strategic spatial planning at all levels of planning. Important goals of the regional policy of Ukraine until 2020 have to be development of rural territories and rational use of potential of natural resources of territories [1]. In this context significant role is played by the issue of spatial planning, as it performs the function of creation of permanent communities by means of physical organization of space according to the general strategy of development of a region or country. In general sense, spatial planning is focused on solution of economic, social and ecological issues of territory development, supporting their permanent interaction [2].

In order to provide transfer from "hard" management of nature use (technical administration of natural systems) to a "soft" one (support of ecological balance of natural systems) at all management levels it is necessary to use the spatial planning for sustainable functioning of a territory. Economic development of regions should be accompanied by measures on protection and reclamation of natural resources, simultaneously providing improvement of living standards of people, regardless of the place of residence. It is necessary to move from extensive type of development to intensive type [3].

These conditions can be fulfilled by means of landscape planning, which are based on maximum consideration of landscape territory diversification, its uniqueness and main functions. Such planning is focused on harmonization of interconnection "society-nature" relations, estimating potential of the territory and determining primary directions of economic activity, arranging the territory of landscapes with consideration of ecological restrictions [4].

The aim of the article is to study landscape-ecological priorities of spatial planning of territories as instruments for efficient management of rural territory development.

Tasks of the research are - to describe methodological aspects of spatial planning of rural territories on local level on landscape-ecological base, and to develop practical recommendations concerning improvement of the system of spatial development of rural territory according to the results of landscape-ecological zoning of the land. 


\section{Materials and methods}

In the research attention is paid to land resources. According to the Food and Agriculture Organization (FAO), land resources are defined as a basis for agriculture and other rural land use. Land resources include physical, biotic, ecological, infrastructural and social-economic components of natural land units. Interaction of these components is of great importance for productivity and stability of agro-ecosystems [5]. Rural territory is considered as a territory outside cities with domination of agricultural, forestry and fishing activities. Landscapes are presented by agricultural land, natural meadows, forests and shrub vegetation, swamps and other land of natural or artificial origin (ravines, pits, ponds, ditches, forest stripes, etc.). In Ukraine, almost $90 \%$ of the area can be considered as rural territories, there $71 \%$ of area is occupied with agricultural land, $18 \%$ - with forests and other forestcovered areas, $2 \%$ - with swamps, $4 \%$ - located under waters, etc. [6].

Methodological base of the research is presented by physical economy, which defines that development of economy is based on the laws of nature (law of biogenic migration of atoms, law of development natural system by means of the surrounding environment, law of optimality, laws of ecology developed by B. Kommoner, and others). The main task of a spatial function of physical economy is modeling of natural order of ecological-social-economic systems performing the process of economic activity [3; 7].

One of the ways of planning of the regional policy in countries of the European Union is planning "bottom-up". It allows realise potential of development of each region of the country [8]. Particularly, the investigation evaluates experience of Germany, where landscape planning is a tool to secure ecological safety and instrument of environmental and landscape management. Under current conditions landscape planning performs informative function, which is revealed in supply of complete, reliable, relevant and operative information about a landscape as geographical complex. Inside the complex, there is an interaction between natural and anthropogenic components, as well as complexes of a lower taxonomic order. This information is necessary for environmental authorities, local governments, landowners, land users and public [9].

The research stresses the approaches to spatial planning on local level, because it allows to make detailed analysis of landscape peculiarities (relief, soil, hydrological conditions, structure of the land, etc.). To give a practical expression of the research results, the authors applied the following methods:

- landscape-ecological approach - to study the location (geosystem) as a multi-structural system;

- cartographic method - for visualisation of proposals concerning planning of the territory on the base of landscape-ecological priorities;

- modelling method - for formation of types of land use, as well as abstract-logical method - to generalize and outline conclusions.

\section{Results and discussion}

Planning measures concerning use and protection of land in Ukraine are developed in city planning and land surveying documents at the national, regional and local levels [10]. Analysis of the documents confirms a lack of integral approach to solution of the problem of sustainable land management, particularly concerning ecological problems and protection of natural potential of the territories, including rural area. City planning documents, which are the basis for decision making in the field of development of territories (expansion of the boundaries of settlements, building of roads and industrial objects, development of build-up territories, etc.), do not completely consider decisions of land surveying documents, describing landscape peculiarities - soils, vegetation, relief and others) $[11 ; 12]$. It complicates the process of land use optimisation in order to satisfy needs of population and protect natural resources for the future generations.

The authors consider that in Ukraine an important component of spatial planning of territory development have to be instruments and approaches, which consider natural peculiarities of a definite territory, its sensitivity to anthropogenic impacts and potential capabilities concerning its efficient use. Content of spatial planning of rural territories on local level, based on landscape-ecological circumstances, is presented by Figure 1. 


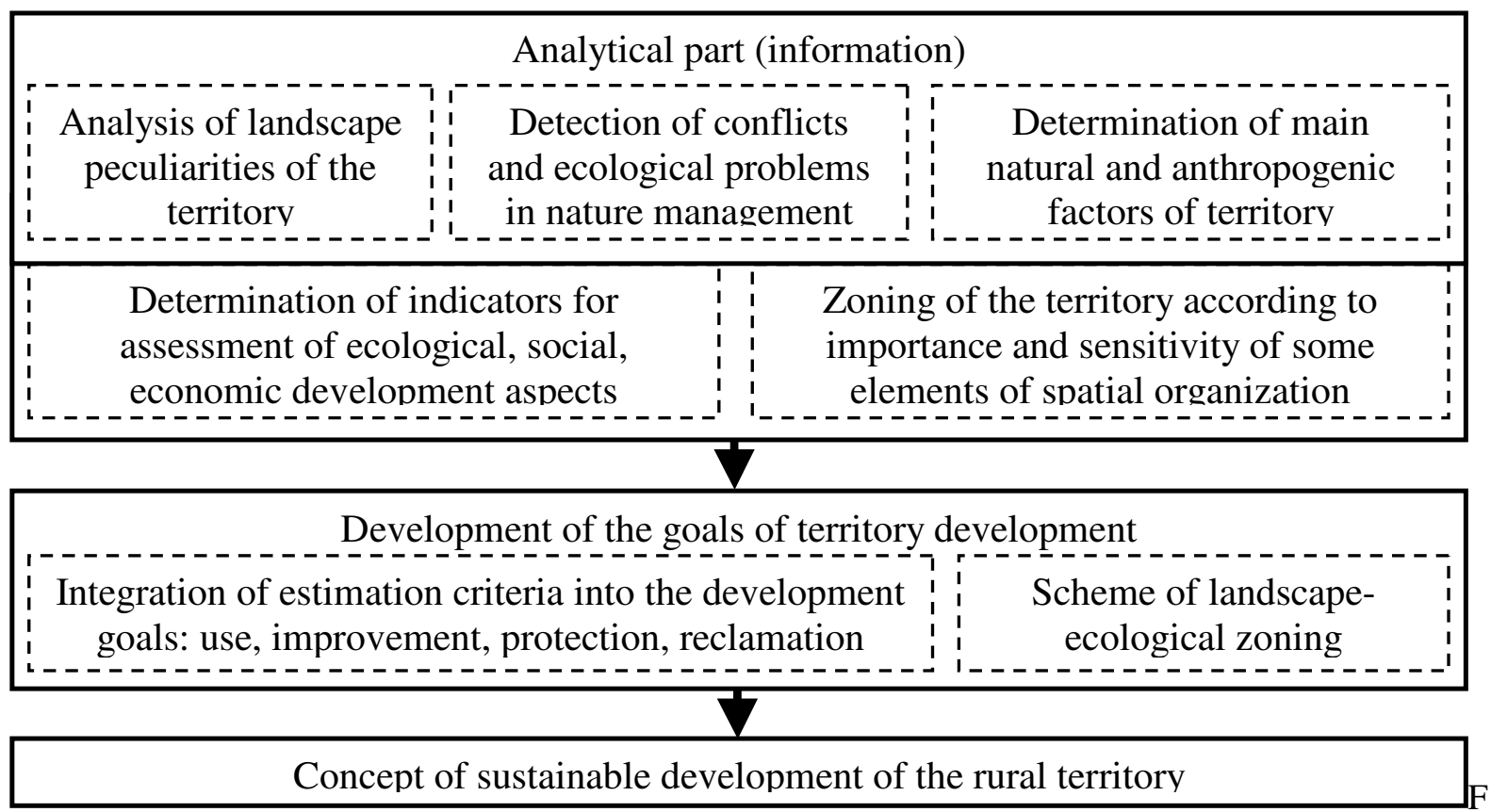

ig. 1. Logical-semantic scheme of spatial planning of rural territory on local level on landscape-ecological base

The authors' opinion is that landscape-ecological oriented planning documents have to make an informative base for projecting of social, productive and environmental protective infrastructure. On local level scheme of landscape-ecological zoning with representation of types of land use, depending on ecological and economic suitability of land use, as well as social and economic needs of population, should create a basis for such documentation. For each type of land use specific regulations have to be determined, which define parameters of ecologically safe land use, considering sensitivity to anthropogenic impacts, e.g. application of soil-protection technologies, implementation of territory organization, reclamation, amelioration, conservation and regeneration of the land, afforestation of the territory, environmental protective use, etc. These regulations also have to be used in determination of a legal status of land use.

Generally, the scheme of landscape-ecological zoning of the land performs the functions as follows:

- ecological - it determines valuable and unique natural areas of ecosystems, sensitive to anthropogenic load land, helps to make preliminary ascertainment of conflicts in land use while implementing the plans and projects of city planning, serves as basis for ecological expertise;

- social - it determines potential territories for recreation, helps to evaluate impact of anthropogenic activity on ecological situation of specific territory and population health, helps to create a safe environment for peoples lives and production of ecologically clean products, informs the people about ecological situation on the territory;

- economic - it is a basis for determination of the most reasonable use of the national and local environmental funds and for ecological certification, helps organize ecologically safe land use to farmers and invest money directly into environmental sector, defines potential land areas for introduction of organic farming.

According to the total area and bio-productive potential of the land stock Lviv region takes a leading position among the regions of Ukraine. Peculiarity of the region has high level of agricultural use of land resources. Agricultural land forms more than $59 \%$ of total area of region, $55 \%$ of agricultural land is arable land. Soil erosion is one of the main destabilizing factors, causing fall of productivity of agricultural land and deterioration of ecological situation in agrarian landscapes of the region.

To test the proposed approach to local level rural area planning on landscape-ecological base, the authors have chosen Remezivtsi municipality in district Zolochiv of Lviv region. This municipality is 
typical for forest-steppe zone and is characterized with fertile soils. $50 \%$ of municipality area consists of arable land. Hilly relief is another characteristic of the territory, because it belongs to HolohoroKremenetske hill-land, has corrugated surface with clearly expressed slopes and micro relief on them. Density of erosion is $2.0-2.5 \mathrm{~km} / \mathrm{km}^{2}$, causing potential losses of soil fertility, particularly on arable land. Analysis of the soil shows that $54 \%$ of arable land has non-eroded soils, $28 \%$ - light eroded, $18 \%$ - heavy eroded. Coefficient of soil erosion $(\mathrm{K})$ is 1.16 , it is critical degree of water-erosion processes [13]. The authors consider that the current conditions of agricultural land use within the studied object do not meet the requirements of rational and ecological use of land resources, as well as other natural resources, securing financial stability of the territorial communities. It determines a necessity to make planning of the territory on the base of a landscape-ecological approach for determination of the territories being sensitive to erosion, as well as argumentation of the regularities concerning their use.

Landscape-ecological planning of the municipality territory was implemented using means of geo-informational modelling in ArcGIS software environment with application of the methods of cartographic overlapping of the layers without changing of their boundaries and cartographic algebra as a set of the functions of mathematic and logical operators. Cartographic modelling is made on the base of a sketch map of the slope degree and length of the slopes of arable land with consideration of the norm of an annual average soil loss for each erosion-dangerous land parcel. Geo-informational modelling has resulted in completing of the scheme of landscape-ecological zoning of the land of Remezivtsi municipality territory (Fig. 2).

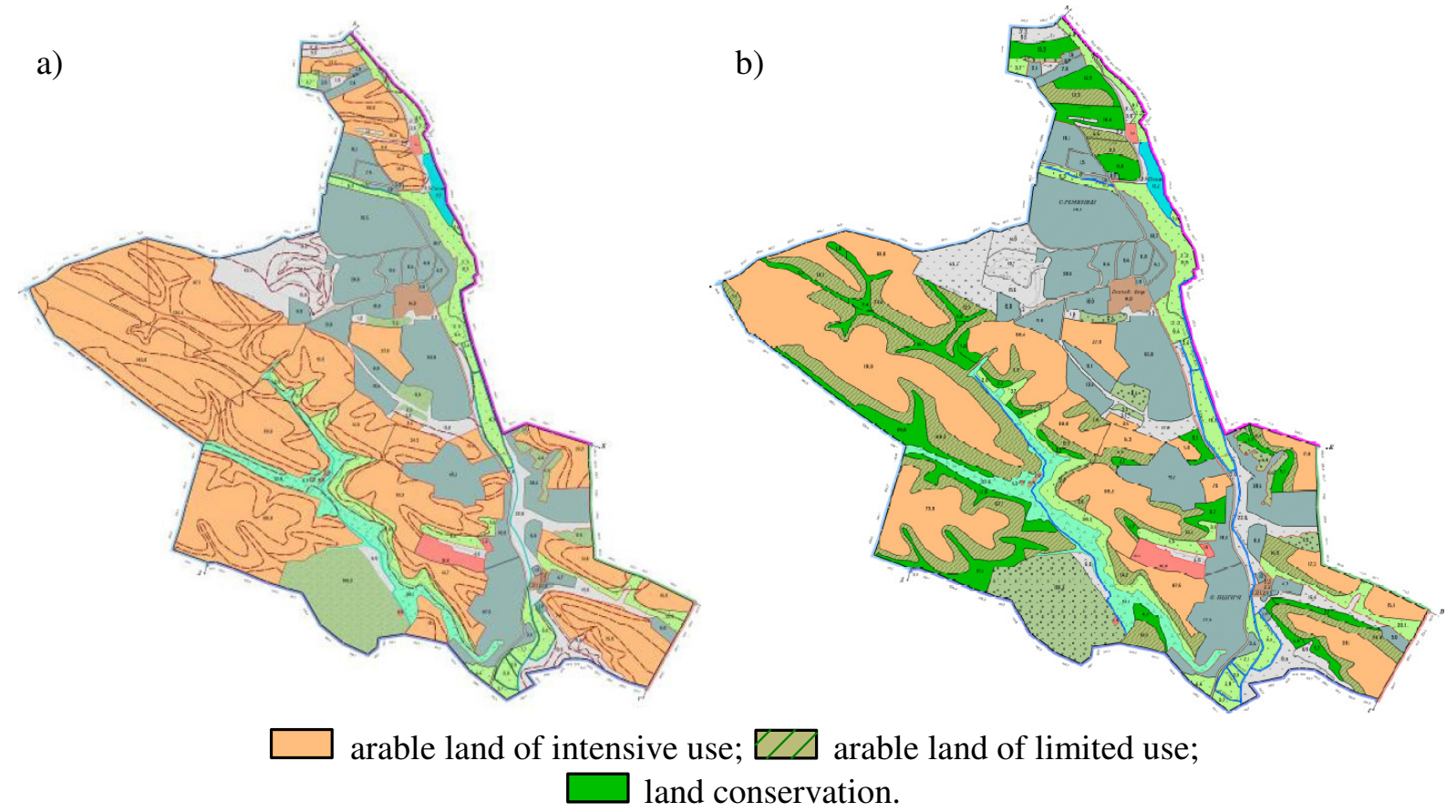

Fig. 2. Land use within Remezivtsi municipality territory: a - current conditions of land use;

$\mathrm{b}$ - land use on the base of landscape-ecological zoning

Within agrarian landscape zone there are determined types of land use according to ecologicaleconomic suitability of arable land, as follows:

- agricultural type of intensive use on the land with non-eroded soils on $0-3^{\circ}$ slopes (652 ha), where soil-protection technologies of soil treatment have to be applied;

- agricultural type of limited use on the land with light eroded soils on $2-5^{\circ}$ slopes ( $\left.387 \mathrm{ha}\right)$, where contour farming has to be applied with limited amount of agricultural crops;

- agricultural type of hayfield-pasture use on the land with heavy eroded soils on $4-6^{\circ}$ slopes and in ravines (225 ha), where land conservation has to be applied (sowing of perennial grainlegume grass mixtures, which do not only protect soil, but support reclamation of destroyed soils, accumulation of humus and increase of their potential fertility) [14]. 
Efficiency of the proposals is estimated by calculating the parameters of water-erosion threat before and after development of the scheme of landscape-ecological zoning of land (Table 1).

Table 1

Indirect assessment of erosion risk on the territory of Remezivtsi municipality territory

\begin{tabular}{|c|l|c|c|}
\hline \multirow{2}{*}{ No. } & \multicolumn{1}{|c|}{ Indicator } & \multicolumn{2}{|c|}{ Characteristics of erosion risk } \\
\cline { 3 - 4 } & $\begin{array}{c}\text { according to the } \\
\text { current conditions }\end{array}$ & $\begin{array}{c}\text { according to the scheme } \\
\text { of land zoning }\end{array}$ \\
\hline 1 & Area under ploughing, \% & high (50) & low (41) \\
\hline 2 & $\begin{array}{l}\text { Correlation between area of arable } \\
\text { land and permanent land, points }\end{array}$ & high (2) & low (1) \\
\hline 3 & Erosion of arable land, \% & high (49) & average (37) \\
\hline 4 & $\begin{array}{l}\text { Area under ploughing on } \\
\text { slopes }>2^{\circ}, \%\end{array}$ & high (42) & average (31) \\
\hline 5 & Degree of erosion risk, points & high (19) & low (9) \\
\hline
\end{tabular}

Degree of erosion risk is qualified using 25-point scale, from insignificant (up to 5 points) to a catastrophic (21-25 points). Analysis of the calculations shows that before planning of the territory on a landscape-ecological base, risk of erosion within the studied object was estimated as high (19 points), but after implementation of the proposed scheme of zoning it will be changed to low only 9 points. Thus, the developed project - conceptual scheme of land zoning within particular territory is a beneficial investment in protection of the value of land resources and it can prevent losses of their productivity.

\section{Conclusions}

1. Research carried out confirms the necessity to consider landscape peculiarities and ecological conflicts in spatial planning. Therefore, in Ukraine for improvement of the system of strategic planning at a local level it is recommended to carry out landscape-ecological zoning of land, and its results have to be considered in determination of functional use of land and development of the concept of sustainable development of rural territories.

2. An important planning document has to be the scheme of landscape-ecological zoning of rural area, which defines types of land use, taken in to account the importance and sensitivity of components to anthropogenic load. Within the studied object it is discovered that soil is sensitive to anthropogenic load, because it is subjected to the process of water erosion due to ploughing of slopes and ravines.

3. It is necessary to set the rules and recommendations for each type of land use according to their ecological-economic suitability. In future it will serve to efficiency of use of natural potential of the territory and support creation of the conditions for its protection and reclamation by means of landscape-ecological organization of the territory.

\section{References}

[1] Про затвердження Державної стратегії регіонального розвитку на період до 2020 року (On the approval of the State Strategy for Regional Development for the period to 2020) Постанова Кабінету Міністрів України від 06.08.2014 № 385. (In Ukrainian). [online] [14.02.2018]. Available at: http://zakon3.rada.gov.ua/laws/show/385-2014- \%D0 \%BF/conv.

[2] UNECE, Spatial Planning - Key Instrument for Development and Effective Governance with Special Reference to Countries in Transition, Report ECE/HBP/146, Geneva UNECE 2008. 46 p.

[3] Реймерс Н.Ф. Экология (теории, законы, правила, принципы и гипотезы) (Ecology (theories, laws, rules, principles and hypotheses). Журнал «Россия Молодая», Москва, 1994. 367 с. (In Russian).

[4] Rudenko L., Maruniak E., Lisovskiy S. Landscape Planning for Ukrainian Rural Communities: Challenges, Outputs, Prospects. Geoadria 19/2. 2014. p. 191-204.

[5] Food and Agriculture Organization of the United Nations: Land \& Water. [online] [15.02.2018]. Available at: http://www.fao.org/home/en/. 
[6] Державна служба з питань геодезії, картографії та кадастру (State Service of Geodesy, Cartography and Cadastre) [online] [11.02.2018]. Available at: http://land.gov.ua/.

[7] Гринів Л.С. Фізична економія: нові моделі сталого розвитку (Physical economy: new models of sustainable development), монографія. Львів, 2016. 424 с. (In Ukrainian).

[8] Регіональний розвиток та державна регіональна політика в Україні: стан і перспективи змін у контексті глобальних викликів та європейських стандартів політики (Regional development and state regional policy in Ukraine: the state and prospects of changes in the context of global challenges and European policy standards). Аналітичний звіт. 341 c. (In Ukrainian).

[9] Haaren C. V., Galler C., Ott S. Landscape planning. The basis of sustainable landscape development. Federal Agency for Nature Conservation. Gebr. Klingenberg Buchkunst Leipzig $\mathrm{GmbH}, 2008.52 \mathrm{p}$.

[10] Stoiko N., Parsova V. Environmental Dimensions of Rural Development in Land Use Planning Circumstances in Ukraine. Engineering for Rural Development: Proceedings of the 16th International Scientific Conference. Vol. 16. Jelgava, 2017. pp. 964-969.

[11]Склад та зміст містобудівної документації на державному та регіональному рівнях (Composition and content of town planning documentation at the national and regional levels) ДБН Б.1.1-13:2012. - Київ. - 27 с. (In Ukrainian).

[12]Про землеустрій (On Land Management) Закон України від 22.05.2003 № 858-IV (In Ukrainian). [online] [14.02.2018]. Available at: http://zakon3.rada.gov.ua/laws/show/858-15.

[13]Булигін С.Ю., Барвінський А.В., Ачасова А.О. Оцінка і прогноз якості земель (Assessment and forecast of land quality), посібник. Харків: Харківський національний аграрний університет, 2006. 262 с. (In Ukrainian).

[14]Шевченко О.В., Мартин А.Г. Економічна ефективність грунтоохоронних заходів при використанні земель сільськогосподарського призначення (Economic efficiency of soil protection measures public in the use of agricultural land), монографія. Київ, 2016. 332 с. (In Ukrainian). 